\title{
PENGARUH BAURAN PEMASARAN RITEL TERHADAP KEPUASAN PELANGGAN MINIMARKET INDOMARET PERUMAHAN SAWOJAJAR I MALANG
}

\author{
Rachmat Agung W \\ Department Of Management FEB UMM \\ Email:Ragung@gmail.com
}

\begin{abstract}
The performance of a retail company is inseparable from the performance attributes of the marketing mix used by retail companies. The marketing mix is generally called on a retail company with ritailing mix. Attribute of ritailing mix consists of product, price, place, promotion, presentation and personnel (6 p). The ritailing mix is also believed to affect the satisfaction of the company's retail customers. So in this study is intended to determine the influence of ritailing mix consisting of attributes of the product, price, place, promotion, presentation and personnel against modern retail customer satisfaction. This research is the research of causality, which aims to explain the influence of the change of variable values in a common variation to the changing value of the variation in one or more other variables. Methods of analysis used in the study are using the multiple linear regression method with sampling purposive sampling method. Data from the questionnaire distributed to 100 customers a minimart Indomaret Sawojajar Housing I Malang became the primary data source. Based on the results of data analysis conducted, it was concluded that a variable price, promotion and presentation which is an attribute of ritailing mix affect significantly to customer satisfaction. While the variable product, place, and influential significance level personnel with a different. This research also concluded that an attribute of ritailing mix are jointly contributing significantly to customer satisfaction with the value of significance 0,000, and has the value of the influence of 58.6\% of customer satisfaction and the rest is influenced by other variables which are not examined in this study.
\end{abstract}

Keywords: Retail, Retailing Mix, and Customer Satisfaction

\section{PENDAHULUAN}

Perkembangan Industri ritel modern seperti supermarket, swalayan, dan minimarket, kian hari kian pesat perkembangannya. Hal ini ditandai dengan banyaknya ritel-retail modern yang bermunculan di berbagai daerah. Menurut Apipun, Data Analyst Manager Frontier Consulting Group (2012), dalam periode enam tahun terakhir, dari tahun 2007-2012, jumlah gerai ritel modern di Indonesia mengalami pertumbuhan rata-rata $17,57 \%$ per tahun. Pada tahun 2007, jumlah usaha ritel di Indonesia masih sebanyak 10.365 gerai, kemudian pada tahun 2011 mencapai 18.152 gerai tersebar hampir di seluruh kota di Indonesia. Hal tersebut memperlihatkan bahwa perilaku berbelanja penduduk Indonesia yang sudah mulai bergeser 
dari berbelanja di pasar tradisional menuju ritel modern.

Menurut laporan dari lembaga survey AC Nielsen, Retail and Shopper Trends Asia Pacific (2010), Indonesia merupakan Negara kedua yang memiliki peningkatan pasar tercepat di kawasan Asia Tenggara dengan tingkat 1,6 persen per tahun, selisih sedikit dari Malaysia yaitu sebesar 1,9 persen per tahun. Dari peningkatan tersebut, 40 persen merupakan hasil dari pertumbuhan pasar modern atau peritail. Sumbangsih yang cukup besar adalah dari menjamurnya ritel lokal jenis minimarket yang menyebar di seluruh pelosok yang memiliki tingakat kepadatan penduduk yang cukup tinggi.

Bauran pemasaran yang mencakup produk, harga, distribusi, dan promosi pada bisnis ritel ditemukan dapat mempengaruhi kepuasan dan loyalitas pelanggan (Harald, dalam Surya \& Setiyaningrum, 2009:14). Tingkat kepuasan pelanggan berhubungan erat dengan kinerja perusahaan ritel termasuk bauran pemasarannya. Apabila suatu perusahaan ritel dapat memenuhi harapan pelanggan, dalam arti pelanggan puas dengan kinerja perusahaan yang ada maka perusahaan tersebut berpotensi untuk mendapatkan pelanggan yang loyal. Sehingga dapat disimpulkan bahwa tingkat kepuasan pelanggan merupakan kunci sukses perusahaan dalam bersaing dan bertahan.

Dalam kaitannnya pada industri ritel, istilah marketing mix yang pada perusahaan ritel biasa disebut dengan ritailling mix. Ritailing mix atau bauran pemasaran ritel ini terdiri dari : lokasi, merchandise, pricing, periklanan dan promosi, atmosfer dalam gerai, dan retail service (Ma'ruf, 2006:13). Sedangkan menurut Lamb dalam Munir (2011:35), atribut ritailling mix diberi istilah 6P yang lebih mudah dipahami yaitu; product, price, place, promotion, presentation, dan personnel.

Salah satu perusahaan ritel terbesar yang mendominasi industri bisnis ritel jenis minimarket di Indonesia saat ini adalah Indomaret. Indomaret merupakan jaringan minimarket yang menyediakan kebutuhan pokok dan kebutuhan sehari-hari yang dikelola oleh PT Indomarco Prismatama. Dengan pengalaman dan capaian Indomaret saat ini tentunya pengelolaaan dan penerapan strategi sudah sesuai denga wheel of retailing. Wheel of retailing adalah proses pertumbuhan sebuah gerai kecil menjadi sebuah perusahaan perdagangan ritel yang besar dimana pengguanaan bauran pemasaran ritel digunakan sebagai pendukung strategi-strategi pemasaran yang digunakan (Ma'ruf, 2006:14).

Pada saat ini kesuksesan Indomaret dalam memperlebar sayapnya dengan penambahan gerai yang begitu besar setiap tahunnya ternyata tidak sejalan dengan prestasi yang di dapat dalam bidang merek, hal tersebut dapat dilihat dari Top Brand Index Indomaret yang cenderung menurun. Indomaret saat ini dapat dilihat pada Tabel 1 . 
Tabel 1

Top Brand Index Minimarket di Indonesia

\begin{tabular}{ccccc}
\hline No & Merek & $\mathbf{2 0 0 9}$ & $\mathbf{2 0 1 0}$ & $\mathbf{2 0 1 1}$ \\
\hline 1 & Alfamart & $47,2 \%$ & $52,1 \%$ & $49, \%$ \\
2 & Indomaret & $38,2 \%$ & $38,1 \%$ & $34, \%$ \\
3 & Alfamidi & $1,0 \%$ & $1,4 \%$ & $2,9 \%$ \\
4 & Cirkel K & $6,4 \%$ & $4,3 \%$ & $2,0 \%$ \\
5 & Yomart & $1,8 \%$ & $1,4 \%$ & $1,7 \%$ \\
\hline
\end{tabular}

Sumber : Hindarmara Research Executive Frontier Consulting Group, 2011

Dari tabel 1 di atas menunjukan bahwa Top Brand Index minimarket Indomaret dari tahun ke tahun mengalami penurunan yaitu dari tahun 2009 ke 2010 dari 38,2 \% menjadi $38,1 \%$, kemudian puncaknya pada tahun 2011 sebesar 34,4\%, dengan menempati urutan ke dua setelah Alfamart. Keadaan tersebut memperlihatkan bahwa komitmen pelanggan untuk berbelanja di minimarket Indomaret mulai menurun. Penurunan tersebut, mengindikasikan bahwa pelanggan mulai kurang puas dengan kinerja atribut-atrbut minimarket Indomaret, termasuk bauran pemasarannya. Melihat fenomena tersebut perlu adanya peninjauan kembali tentang bauran pemasaran ritail yang digunakan Indomaret, berkaitan dengan tingkat kepuasan pelanggannya.

\section{TINJAUAN PUSTAKA}

Kata ritel berasal dari bahasa perancis, ritellier, yang berarti memotong atau memecah sesuatu. Terkait dengan aktivitas yang dijalankan, maka ritel menunjukan upaya untuk memecah barang atau produk yang diahasilkan dan didistribusikan oleh manufaktur atau perusahaan dalam jumlah besar atau masal untuk dapat dikonsumsi oleh konsumen akhir dalam jumlah kecil sesuai dengan kebutuhannya. Kebutuhan keberadaan ritel sejalan dengan kebutuhan konsumen yang menginginkan barang maupun jasa sejumlah mereka butuhkan pada saat, tempat, dan waktu tertentu tanpa harus menyimpan (Utami, 2010:4).

Menetapkan pasar sasaran merupakan syarat untuk menetapkan strategi ritel. Strategi pemasaran ritel adalah kegiatan usaha di bidang ritel yang berhubungan dengan bauran pemasaran ritel atau disebut dengan ritailing mix (Sarjono, 2012:52). Bauran pemasaran ritel (ritailing mix) adalah strategi pemasaran yang mengacu pada beberapa variabel, dimana paritel dapat mengkombinasikan variabel-variabel tersebut menjadi jalan alternatif dalam upaya menarik konsumen (Utami, 2010:86).

Menurut Harald, dalam Surya \& Setiyaningrum, (2009:14) bauran pemasaran yang mencakup produk, harga, distribusi, dan promosi pada bisnis ritel ditemukan dapat mempengaruhi kepuasan dan loyalitas pelanggan. Dalam perkembangannya retailing mix dibagi menjadi enam, yaitu; lokasi, merchandise, pricing, periklanan dan promosi, atmosfer dalam gerai, dan retail service (Ma'ruf, 2006:13). Hal tersebut juga tidak jauh berbeda dengan apa yang di paparkan Lamb dalam Munir (2011:35), retail mix terdiri dari; keluasan dan kedalaman keragaman produk (product), keputusan penetapan harga dalam setiap produk (price), penempatan lokasi yang startegis dalam bersaing 
(place), memperkenalkan merek dalam benak konsumen (promotion), suasana atau atmosfer dalam gerai yang sekiranya menentukan konsumen dalam pengambilan keputusan membeli atau tidak (presentation), pelayanan pelanggan dan penjualan pribadi (personnel).

Menurut Lupiyoadi \& Hamdani (2006:193) kepuasan pelanggan berhubungan erat dengan kienrja atribut-atribut sebuah perusahaan. Atribut-atribut dalam usaha ritel merupakan bagian dari aplikasi bauran pemasaran ritel (ritailling mix) yang digunakan. Dengan demikian maka apabila kinerja atribut sesuai dengan apa yang di harapkan pelanggan maka pelanggan akan merasa puas.

Secara umum, kepuasan (satisfaction) merupakan perasaan senang atau kecewa seseorang yang timbul karena membandingkan kinerja yang dipersepsikan produk atau hasil dari expektasi mereka (Kotler \& Keller, 2009:138). Jika kinerja gagal memenuhi ekspektasi, maka pelanggan akan merasa tidak puas. Sedangkan jika kinerja sesuai dengan ekspektasi, pelanggan akan puas dan jika kenerja melebihi ekspektasi, pelanggan akan merasa sangat puas atau senang.

Pada penelitian yang dilakukan oleh Faizul, (2009:5) menjelaskan secara serempak bauran pemasaran eceran yang terdiri dari produk, pelayanan toko, desain toko dan atmosfir toko, harga, promosi dan lokasi berpengaruh terhadap kepuasan konsumen, dengan tingkat pengaruh yang sangat signifikan. Sedangkan penelitian yang dilakukan oleh Paramita (2010) dengan memebagi retail mix menjadi 8 atribut menjelaskan bahwa tidak semua variabel bauran pemasaran berpengaruh terhadap kepuasan pelanggan.

Model konsep yang dikembangkan dalam penelitian ini menggambarkan pengaruh variabelvariabel independen yang terdiri dari product, price, place, promotion, presentation dan personel (6P) sebagai atribut bauran pemasaran ritel (retailing mix) terhadap kepuasan pelanggan sebagai variabel dependen. Model konsep pada penelitian ini dapat dilihat pada gambar 1 .

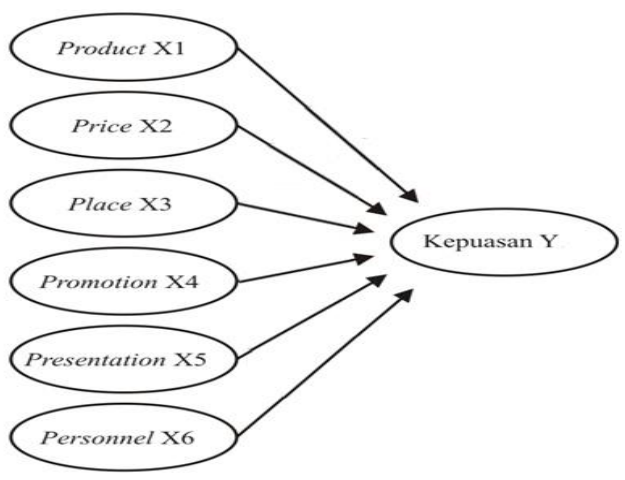

Gambar 1. Model Kosep Bauran

Pemasaran Ritel Terhadap Kepuasan Pelanggan.

\section{METODE PENELITIAN}

Penelitian ini dilakukan di 4 (empat) minimarket Indomaret Perumahan Sawojajar I Malang yang berlokasi di Jalan Danau Sentani, Jalan Danau Krinci, Jalan Danau Limboto dan Jalan Danau Tondano Perumahan Sawojajar I Malang.

Desain penelitian ini adalah desain kausal yaitu termasuk salah satu bentuk penelitian konsklusif dimana tujuan utamanya adalah hubungan sebab dan akibat antar satu 
variable dengan variable lain (Widayat, 2002:41) Permasalahan yang ditampilkan dalam penelitian ini merupakan permasalahan yang dianjurkan oleh para peneliti terdahulu, yang membutuhkan dukungan untuk fakta yang terbaru.

Untuk penelitian ini populasi adalah semua pelanggan minimarket Indomaret Perumahan Sawojajar I Malang. Sedangkan penentuan sampel dalam penelitian ini bersifat tidak acak (nonprobability sampling), dimana anggota populasi tidak diberi peluang yang dapat dihitung untuk dipilih menjadi anggota sampel (Wiyono, 2011:88). Dalam penelitian ini, metode pengambilan sampel dengan menggunakan metode Purposive Sampling, yaitu pengambilan sampel yang berdasarkan pertimbangan tertentu dan harus representative / mewakili populasi yang akan diteliti, prtimbangan yang digunakan dalam penelitian ini adalah pelanggan yaitu konsumen yang berbelanja lebih dari satu kali di minimarket Indomaret Perumahan Sawojajar I Malang dengan batasan usia 15 tahun ke atas dengan jumlah sampel sebanyak 100 responden.

Sumber data dalam penelitian ini adalah data primer yang merupakan data yang dikumpulkan dari sumber pertama baik dari individu maupun perorangan sehingga data primer merupakan data yang diperoleh langsung dari subjek penelitian diamati dan dicatat untuk pertama kalinya melalui hasil pengisian kuesioner.

Adapun pada penelitian ini, skala pengukuran jawaban kuesioner yang digunakan adalah skala interval 1-5. Sedangkan tekhnik penskalaan yang digunakan adalah menggunakan skala likert. Skala ini dipergunakan untuk mendapatkan data mengenai bobot setiap jawaban yang deberikan oleh responden. (Wiyono, 2011:96).

Validitas data hasil kuesioner dilakukan untuk mengetahui apakah isi kuesioner dipahami oleh responden dengan cara mengorelasikan antara skor item dengan skor total item. Reliabilitas adalah ukuran seberapa besar keandalan suatu intrumen pengumpulan data. (Wiyono, 2011:115-116).

Menurut Ghozali dalam Munir (2011:60) menyatakan bahwa analisis regresi linear berganda pada dasarnya merupakan perluasan dari regresi linear sederhana yaitu dengan menambah jumlah variabel bebas yang sebelumnya hanya satu menjadi dua atau lebih. Alasan penggunaan metode analisis data dengan regresi linear berganda yaitu pertama, dalam penelitian mencari pengaruh. Kedua, Regresi mampu mendeskripsikan fenomena data melalui terbentuknya suatu model hubungan yang sifatnya numerik.

\section{HASIL PENELITIAN DAN PEMBAHASAN}

Hasil Uji Validitas pada penelian ini diketahui bahwa nilai $r$ hitung pada semua item pernyataan lebih besar daripada $r$ tabel, sehngga dapat dikatakan bahwa instrumen yang digunakan sudah dapat mengukur variabel product, price, place, promotion, presentation, personnel dan kepuasan.

Berdasarkan perhitungan dapat diketahui bahwa variabel product, price, place, promotion, presentation, personnel dan kepuasan. yang 
dimasukkan dalam pernyataan kuesioner mempunyai nilai reliabilitas yang lebih besar daripada nilai kritis 0,60 (teknik alpha) sehingga dapat dikatakan konsisten (reliabel) untuk digunakan dalam penelitian ini.

Pada penelitian ini, jumlah kunjungan yang pernah dilakukan responden di minimarket Indomaret perumahan Sawojajar I Malang, memperlihatkan dari 100 responeden, 90\% pernah berbelanja di minimarket indomaret lebih dari 4 kali. Sehingga dapat disimpulkan bahwa sebagian besar reponden merupakan pelanggan loyal minimarket Indomaret Perumahan Sawojajar I Malang.

Pada penelitian ini mayoritas konsumen minimarket Indomaret yaitu sebesar $63 \%$ adalah konsumen yang berjenis kelamin perempuan dan sisanya adalah laki-laki. Hal tersebut dikarenakan perempuan mempunyai kecenderungan lebih sering berbelanja dibandingkan dengan lakilaki. Selain itu sebagian besar produkproduk yang dijual di Indomaret meruapakan produk kebutuhan rumah tangga diamana untuk pemenuhan kebutuhan keluarga lazimnya dilakukan oleh kaum perempuan.

Pada penelitian ini mayortas responden yaitu sebanyak 36\% berada pada kelompok usia 21 - 30, dimana usia tersebut merupakan usia muda yang lebih suka berbelanja pada tempat yang menarik dan nyaman. Prosentase terbesar kedua adalah kelompok usia 31 sampai 40 tahun sebanyak $26 \%$ sehingga disimpulkan bahwa mayoritas usia responden berada pada tingkat muda samapai dewasa.

Pada penelitian ini mayoritas responden sebesar $42 \%$ berpendidikan terakhir SMA/Sederajat. Hasil pengamatan peneliti menunjukkan bahwa sebagian besar responden adalah mahasiswa dan sebagian kalangan ibu rumah tangga yang memiliki tingkat kebutuhan akan pendidikan yang kurang tinggi. Setelah lulus SMA/Sederajat, mayoritas lebih memilih bekerja dan berkeluarga dibandingkan meneruskan tingkat pendidikannya ke jenjang yang lebih tinggi.

Pada penelitian ini mayoritas 'responden minimarket Indomaret sebesar 32\% adalah ibu rumah tangga. Hal tersebut berkaitan dengan kegiatan yang sering dilakukan oleh ibu rumah tangga dimana kegiatan berbelanja untuk pemenuhan kebutuhan rumah tangga merupakan kwajiban dari kalangan ini.

Dari uraian karakteristik responden yang telah terpapar, dimulai dari jumlah kunjungan hingga karekteristik berdasarkan jenis pekerjaan dapat disimpulkan mayoritas responden merupakan kalangan ibu rumah tangga muda, yang loyal berbelanja di minimarket Indomaret. Hal tersebut berkaitan dengan pemenuhan kebutuhan seharihari dimana kalangan ibu rumah tangga muda ini lebih memilih tempat belanja yang nyaman dan menarik.

Hasil uji normalitas pada penelitian ini dapat dilihat pada tabel 2. 
Tabel 2. Hasil Uji Normalitas

Asymp. Sig. (2- $\quad 0,982$ tailed)

Dari hasil uji normalitas yang terlihat pada tabel 4, dengan pengujian One-Sample KolmogorovSmirnov yang dilakukan dengan bantuan software SPSS 15.0., dari tampilan di atas terlihat pada Asymp. Sig. (2-tailed) memiliki nilai sebesar 0,982, yang berarti lebih besar dari nilai signifikansi yang disyaratkan yaitu sebesar 0,05 atau 5\%, sehingga dari pengujian uji normalitas dapat disimpulkan data berdistribusi normal.

Dari hasil output pengujian yang bahwa t hitung postif lebih kecil dari $\mathrm{t}$ tabel positif. Sedangkan $\mathrm{t}$ hitung negatif lebih lebih besar dari t tabel negatif. Karena nilai t hitung berada pada $-\mathrm{t}$ tabel $\leq \mathrm{t}$ hitung $\leq \mathrm{t}$ tabel, maka memeberikan arti pengujian diantara variabel tidak ada gejala heteroskedasitas. Dengan demikian dapat disimpulkan bahwa tidak ditemukan masalah heteroskedasitas pada model regresi.

Metode pengujian pada analisis data ini menggunakan uji DurbinWatson (uji DW). Kententuan pada uji DW yaitu jika DW < dari dL atau DW > (4-dL) maka terdapat autokorelasi, dan jika DW terletak antara dU dan (4-dU) maka tidak terdapat autokorelasi. Pada tabel 4.16 dapat dilihat bahwa nilai DW sebesar 2,185 . Sedangkan dari tabel DurbinWatson (DW) denagn signifikansi 0,05 dengan jumlah data $(n)=100$, dan jumlah variabel independen $(\mathrm{k})=$ 6, menghasilkan nilai dU sebesar 1,803 dan dL sebesar 1,550. Dari uji tersebut nilai DW sebesar 2,185 berada anatar nilai dU sebesar 1,803 dan 4-dU sebesar 2,197, maka data dapat dinyatakan tidak terdapat autokorelasi.

Hasil olahan data regresi linear berganda dengan menggunakan program SPSS 15.0. (Statistical Package for Social Science 15.0) dengan metode Enter dirangkum pada tabel 3 .

Tabel 3. Hasil Perhitungan Rgresi

Liniar Berganda Metode Enter

\begin{tabular}{|c|c|c|c|c|}
\hline $\begin{array}{l}\text { Variabel } \\
\text { Terikat }\end{array}$ & $\begin{array}{c}\text { Variabel } \\
\text { Bebas }\end{array}$ & b & $\begin{array}{c}\text { t- } \\
\text { hitun } \\
\text { g }\end{array}$ & $\begin{array}{c}\text { Sig. } \\
\mathbf{t}\end{array}$ \\
\hline Kepuasan & $\mathrm{a}$ & 0,4 & 1,321 & 0,23 \\
\hline \multirow[t]{9}{*}{ Pelanggan } & $\begin{array}{l}\text { (Constan } \\
\text { t) }\end{array}$ & 21 & & 0 \\
\hline & Product & $\begin{array}{l}0,0 \\
31\end{array}$ & 0,275 & $\begin{array}{c}0,76 \\
3\end{array}$ \\
\hline & Price & $\begin{array}{l}0,3 \\
69\end{array}$ & 4,910 & $\begin{array}{c}0,00 \\
0\end{array}$ \\
\hline & Place & $\begin{array}{l}0,1 \\
21\end{array}$ & 1,623 & $\begin{array}{c}0,09 \\
4\end{array}$ \\
\hline & Promotio & 0,1 & 2,661 & 0,00 \\
\hline & $n$ & 43 & & 9 \\
\hline & Presentat & $\begin{array}{l}0,3 \\
17\end{array}$ & 3,317 & $\begin{array}{c}0,00 \\
1\end{array}$ \\
\hline & Personne & 0,0 & 0,231 & 0,82 \\
\hline & $l$ & 35 & & 3 \\
\hline F hitung & 24,112 & & & \\
\hline $\begin{array}{c}\text { Adjusted } \\
\mathrm{R}^{2}\end{array}$ & 0,591 & & & \\
\hline
\end{tabular}

Sumber : Lampiran

Dari tabel diperoleh hasil bahwa nilai konstanta (a) $=0,421$; nilai regresi $(b 1)=0,031$; nilai regresi $(b 2)$ $=0,369$; nilai regresi $(\mathrm{b} 3)=0,121$; nilai regresi $(b 4)=0,143$; nilai regresi (b5) $=0,317$ dan nilai regresi $(\mathrm{b} 6)=$ 0,035 . Dengan demikian maka persamaan regresi bergandanya menjadi :

$$
\begin{aligned}
& Y=0,421+0,031 X 1+0,369 X 2 \\
& +0,121 X 3+0,143 X 4+0,317 X 5+ \\
& 0,035 X 6+e
\end{aligned}
$$


Atribut product memiliki pengaruh yang tidak signifikan terhadap kepuasan pelanggan minimarket Indomaret Perumahan Sawojajar I Malang. Hal ini dapat terjadi karena kebanyakan produkproduk yang dijual di minimarket Indomaret hampir sama dengan produk yang dijual di minimarket lain ataupun toko ritel sejenis sehingga tingkat kepuasan pelanggan tidak terlalu ditentukan oleh variabel product dari bauran pemasaran ritel minimarket Indomaret.

Atribut price memiliki pengaruh yang signifikan terhadap kepuasan pelanggan minimarket Indomaret Perumahan Sawojajar I Malang. Hal ini dapat terjadi karena apabila strategi harga dari produk yang dijual di minimarket Indomaret sesuai dengan apa yang diharapkan pelanggannya ataupun harga yang diberikan lebih murah dibandingkan dengan minimarket lain ataupun ritel sejenis maka akan membuat pelanggan tersebut menjadi puas dan berlaku sebaliknya apabila strategi harga dari produk yang dijual di minimarket Indomaret tidak sesuai dengan apa yang diharapkan pelanggannya ataupun harga yang diberikan lebih mahal dibandingkan dengan minimarket lain ataupun ritel sejenis maka akan membuat pelanggan tersebut menjadi tidak puas.

Atribut place memiliki pengaruh yang tidak signifikan terhadap kepuasan pelanggan minimarket Indomaret Perumahan Sawojajar I Malang. Hal ini dapat terjadi karena kebanyakan atribut place atau tempat dari minimarket Indomaret hampir sama dengan tempat minimarket lain ataupun ritel sejenis dimana ritel modern mayoritas memiliki lokasi berjualan yang strategis dan lokasi dari ritel ini berdekatan sehingga tingkat kepuasan pelanggan tidak ditentukan oleh variabel place dari bauran pemasaran ritel minimarket Indomaret.

Atribut promotion memiliki pengaruh yang signifikan terhadap kepuasan pelanggan minimarket Indomaret Perumahan Sawojajar I Malang. Hal ini dapat terjadi karena apabila strategi promosi yang diterapkan di minimarket Indomaret sesuai dengan apa yang diharapkan pelanggannya maka akan memberikan kesan menarik pada pelanggannya untuk berbelanja di minimarket tersebut dan akhirnya akan membuat pelanggan tersebut menjadi puas dalam berbelanja.

Atribut presentation memiliki pengaruh yang signifikan terhadap kepuasan pelanggan minimarket Indomaret Perumahan Sawojajar I Malang. Hal ini dapat terjadi karena minimarket Indomaret memiliki tampilan dari sebuah toko ritel yang manarik serta nyaman untuk berbelanja sehingga akan memberikan tingkat kepuasan bagi pelanggannya dalam berbelanja di minimarket tersebut.

Atribut personnel memiliki pengaruh yang tidak signifikan terhadap kepuasan pelanggan minimarket Indomaret Perumahan Sawojajar I Malang. Hal ini dapat terjadi karena atribut personnel dari bauran pemasaran ritel minimarket Indomaret terutama dari segi pelayanan dinilai masih kurang maksimal, dimana tidak semua dari pramuniaga minimarket Indomaret dalam memeberikan pelayanan terhadap pelanggannya belum 
memberikan kinerja yang memuaskan, contohnya saja dari segi salam atau sapa yang menjadi standar pelayanan dari perusahaan, tidak semua pramuniaga di minimarket Indomaret melakukannya dengan sepenuh hati, masih banyak pramuniaga yang hanya sekedar menjalankan tugas dalam menyapa pelanggannya.

Atribut product, price, place, promotion, presentation, dan personnel yang merupakan atribut bauran pemasaran ritel berpengaruh positif terhadap kepuasan pelanggan dan secara simultan ada pengaruh yang signifikan antara product, price, place, promotion, presentation, dan personnel terhadap kepuasan pelanggan minimarket Indomaret Perumahan Sawojajar I Malang.

\section{SIMPULAN}

Secara parsial dapat disimpulkan bahwa atribut product, place dan personnel dari bauran pemasaran ritel tidak memiliki pengaruh yang signifikan terhadap kepuasan pelanggan. Secara parsial dapat disimpulkan bahwa atribut price, promotion dan presentation dari bauran pemasaran ritel memiliki pengaruh yang signifikan terhadap kepuasan pelanggan. Secara simultan terdapat pengaruh yang signifikan secara bersama-sama antara variabel product, price, place, promotion, presentation, dan personnel yang merupakan atribut bauran pemasaran ritel terhadap kepuasan pelanggan.

Pandangan responden akan atribut product, price, place, promotion, presentation, dan personnel dari bauran pemasaran ritel serta tingkat kepuasan pelanggan dari minimarket Indomaret Perumahan
Sawojajar I Malang berdasarkan ratarata jawaban responden sudah baik.

\section{DAFTAR PUSTAKA}

AC Nielsen. 2010. Retail and Shopper Trends Asia Pacific 2010. Articles. www.nielsen.com.

Apipudin. 2012. Data Analyst Manager Frontier Consulting Group - Brand Switching Analysis dalam Industri Ritel Modern. Articles. October 30, 2012. www.frontier.co.id.

Darandono. 2012. Indomaret Targetkan Tambah 1.000 Outlet di 2013, Articles. December 22, 2012. www.swa.co.id

Faizul. Ahmad. 2009. Pengaruh Strategi Bauran Pemasaran Ritel Terhadap Kepuasan Dan Hubungannya Dengan Loyalitas Pelanggan Plaza Medan Fair Di Medan. Sekripsi. Universitas Sumatra Utara.

Hindarmara, Andre. 2011. Data Research Executive Frontier Consulting Group - Kunci Sukses Ritel Membangun Merek. Articles. September 5, 2011. www.frontier.co.id.

Kotler, Philip, \& Keller. Kevin Lane . 2009. Manajemen Pemasaran Jilid 1 dan 2, edisiKetiga Belas. Penerbit Erlangga.. Jakarta.

Lupiyoadi. Rambat \& Hamdani. A. 2006. Manajemen Pemasaran Jasa. Penerbit Salemba Empat. Jakarta.

Ma'ruf. Hendri. 2006. Pemasaran Ritel. Penerbit PT. Gramedia Utama. Jakarta. 
Mattsson. Katriina. 2009. Customer Satisfaction In The Retail Market Case Company Gant Store. Degree Programme of International Business. Finland. University Of Applied Sciences.

Munir. M. Misbakhul. 2011. Analisis Pengaruh Retailing Mix Terhadap Keputusan Pembelian Pada Mini Market Permata Di Kecamatan Balapulang. Sekripsi. Universitas Diponegoro Semarang.

Paramita. Ginanda. 2010. Pengaruh Aplikasi Bauran Pemasaran Terhadap Kepuasan Pelanggan Toko Modern (Studi Kasus Pada Carrefour Di Depok). Sekripsi. Universitas Gunadarma Bekasi.

Porwati. 2009. Analisis Loyalitas Konsumen Giant Hypermarket Taman Yasmin, Bogor. Sekripsi. Institut Pertanian Bogor.

Samuel. Hatane. (2006). Ekspektasi Pelanggan dan Aplikasi Bauran Pemasaran terhadap loyalitas Toko Moderen dengan Kepuasan Pelanggan sebagai Intervening (Studi Kasus pada Widayat. 2004. Metode Penelitian Pemasaran Aplikasi Sofware SPSS. Penerbit UMM Press. Malang.
Hypermarket Carrefour di Surabaya). Jurnal Manajemen Pemasaran.Vol. 1, No. 2 . Oktober 2006: 53-64.

Sarjono. Bambang. 2012. Bauran Pemasaran Bisnis Ritel. Jurnal Bisnis dan Kewirausahaan. Vol. 8 No. 1 Maret 2012: 50-55.

Setiyawati. Antari, SE. 2009. Studi Kepuasan Pelanggan Untuk Mencapai Loyalitas Pelanggan (Studi Kasus Pada Konsumen Toko Bangunan Bangun Rejeki Semarang). Tesis. Universitas Diponegoro Semarang.

Surya, Aristo \& Setiyaningrum. Ari. 2009. Analisis Persepsi Konsumen Pada Aplikasi Bauran Pemasaran Serta Hubungannya Terhadap Loyalitas Konsumen (Studi Kasus Pada Hypermart Cabang Kelapa Gading). Journal of Business Strategy and Execution. 2 2009: 13 - 39.

Utami. C. Whidiya. 2010. Manajemen Ritel. Penerbit Salemba Empat. Jakarta.

Widarjono. Agus. 2010. Analisis Statistika Multivariat Terapan. Penerbit Unit Penerbitan dan Percatakan STIM YKPN. Yogyakarta.

Wiyono. 2011. Merancang Penelitian Bisnis dengan Alat Analisis SPSS 17.0 dan Smart PLS 2.0. Penerbit STIM YKPN. Yogyakarta 